\title{
Augmented/Virtual Reality Promises for ELT Practitioners
}

\section{Mehrasa Alizadeh \\ Osaka University}

\section{Reference Data:}

Alizadeh, M. (2019). Augmented/virtual reality promises for ELT practitioners. In P. Clements, A. Krause, \& P. Bennett (Eds.), Diversity and inclusion. Tokyo: JALT.

Augmented reality (AR) and virtual reality (VR) are expanding into various fields of education. Thanks to $A R$ and $V R$, teachers can bring a whole new dimension to the realm of language education, resulting in enhanced learning and increased motivation and engagement. With smartphones and inexpensive VR headsets, teachers are able to take a step forward in blurring the boundaries between the real and virtual worlds, giving their students immersive learning experiences. However, many ELT practitioners are not familiar with or keen on integrating AR/ VR-related learning tools and resources into their classes (Bonner \& Reinders, 2018; Santos et al., 2016). To get readers more acquainted with AR/VR uses in language education, the author first outlines the basic concepts within this area of research and practice. An AR/VR application is introduced in detail, followed by discussion on the use of this app in language learning

拡張現実 (AR) および仮想現実 (VR) は絶えず様々な教育分野に拡大している。ARとVRによって、学習の強化やモチベーショ ンとエンゲージメントの向上が可能となり、言語教育の領域に全く新しい次元をもたらすことができる。スマートフォンや安価 なVRヘッドセットの使用によって、現実世界と仮想世界の境界を曖昧にすることで、学生は没入型の学習体験を得られる。し かし、ELT実務家の多くは、AR・VR関連の学習ツールとリソースを教育実践に統合する方法に馿染みがなかったり、統合自体に 関心がない現状がある(Bonner \& Reinders, 2018; Santos et al., 2016)。読者の言語教育におけるAR・VRの使用法に関する詳 細な理解を深めるために、まずての分野の研究と実践の基本的な概念を概説する。また、AR及びVRアプリケーションについて 詳しく説明した上で、このアプリケーションを言語学習に使用する方法について説明する。 ince the emergence of augmented reality (AR) and virtual reality (VR) in the 20th $\checkmark$ century, these technologies have found their way into the military, entertainment/ gaming, advertisement/marketing, and the aviation industry (Craig, 2013; Kipper \& Rampolla, 2013; Sherman \& Craig, 2003; van Arnhem, Rose, \& Elliott, 2018). Some fields of education including science and medicine have also greatly benefited from AR and VR integration; however, the use of AR and VR in language learning contexts is still in its infancy, with an increasing number of papers published only over the past decade (Bonner \& Reinders, 2018; Hastings \& Brunotte, 2017; Hawkinson, 2014; Lege \& Bonner, 2018). AR and VR could be a useful form of technology in L2 teaching and learning as they have the potential to bring a whole new dimension to the realm of language education resulting in enhanced learning and increased motivation and engagement, as evidenced in the literature. For example, Li, Chen, Whittinghill, and Vorvoreanu (2014) found that an AR flash card application (app) they experimented with had the potential to increase college students' vocabulary learning motivation, though some technical issues had yet to be overcome. Similarly, as Gadelha (2018) and Lloyd, Rogerson, and Stead (2017) maintained, VR can provide students with immersive learning experiences by merging the boundaries between the worlds inside and outside the classroom.

Similar to any new technology making its move to center stage, the affordances of AR and VR have not yet been sufficiently explored by many ELT practitioners, and teachers may not be keen on or may be simply intimidated by incorporating AR/VR-related learning tools and resources into their classes (Bonner \& Reinders, 2018; Santos et al., 2016). In order to raise the awareness of this group of AR/VR uses in language education, a free AR/VR app developed by Google will be introduced, accompanied with discussion on the use of this app in language learning contexts. Ideas for augmented/virtual-realityenhanced classroom tasks and activities will also be introduced. Finally, JALT's newly formed special interest group, the Mixed, Augmented, and Virtual Realities in Learning (MAVR) SIG, will be introduced as a community for readers who would like to further explore AR and VR apps in language pedagogy. 


\section{The Basics of Augmented and Virtual Reality}

\section{Reality-Virtuality Continuum}

In order to better understand the differences between AR and VR, it is best to look at the reality-virtuality continuum proposed by Milgram, Takemura, Utsumi, and Kishino (1994), displayed in Figure 1. Imagine a continuum with the real environment and the virtual environment on the two extremes. In a virtual environment, one is surrounded by unreal objects while being completely separated from the real environment. As one moves toward the middle of the continuum from either side, there is a mix of the real and the virtual, labeled as mixed reality (MR). Depending on the proportion of this blend, the new environment could be close to AR, where there is more of the real environment with the presence of digital objects interacting with real ones, or augmented virtuality $(\mathrm{AV})$, which has more attributes of the virtual world with some real objects present.

\section{Mixed Reality (MR) — \\ Real $\longrightarrow$ Augmented \\ Augmented $\longleftarrow$ Virtual Environment Reality (AR) Virtuality (AV) Environment}

Figure 1. Reality-virtuality continuum, adapted from Milgram, Takemura, Utsumi, and Kishino (1994).

As already mentioned, this paper deals with AR and VR and is aimed at exploring their affordances in language learning. According to Kipper and Rampolla (2013), AR refers to "taking digital or computer-generated information, whether it be images, audio, video, or touch or haptic sensations and overlaying them over in a real-time environment" (p. 1).

VR has also been defined as "an immersive computer-enabled technology that replicates an environment and allows a simulation of the user to be present and interact in that environment" (Lloyd, Rogerson \& Stead, 2017, p. 222). In what follows, I will describe ways in which one can experience AR and VR.

\section{Experiencing $A R$ \& VR}

VR can be experienced using VR headsets such as the inexpensive Google Cardboard or more advanced yet costly head mounted displays (HMDs) such as Oculus Rift or HTC Vive. The latter HMDs are capable of tracking user motion and simulating a virtual environment in which users can move, pick up things, and perform different actions using controllers pretty much in the same way they do in the real environment. Nonetheless, higher costs as well as software and hardware requirements have restricted their use in educational contexts. Google Cardboard, however, is an inexpensive VR viewer than can be purchased in large numbers at a moderate cost (see Figure 2). It was first released in 2014 and has been highly favored by teachers due to its affordability. It is worth noting that VR experienced with Google Cardboard is different from the type provided by more advanced HMDs such as the Vive or the Rift. VR content that can be viewed with Google Cardboard and a smartphone is basically a spherical or $360^{\circ}$ video or photo, an environment in which the user cannot walk or approach the surrounding objects, but even so, it can be sufficiently immersive and engaging to users.

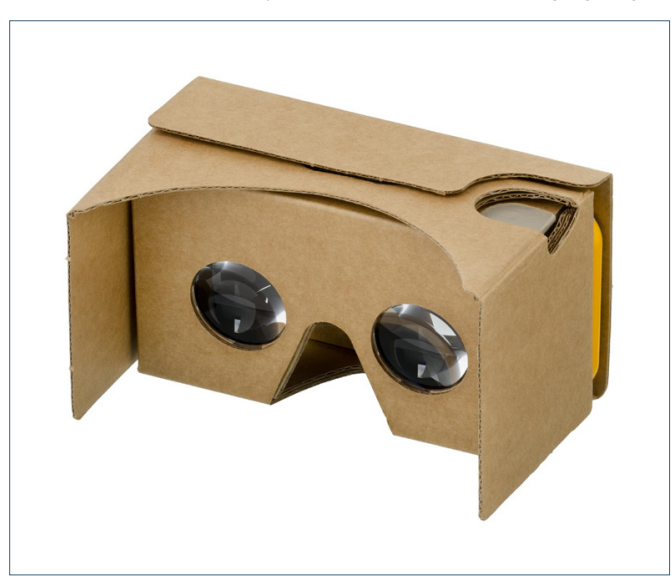

Figure 2. Google Cardboard (photo by Evan-Amos-own work, public domain, https:// commons.wikimedia.org/w/index.php?curid=45580283).

AR apps and platforms, such as HP Reveal (formerly known as Aurasma, https://www. hpreveal.com/), Wikitude (https://www.wikitude.com/), Layar (https://www.layar.com/), and Augment (https://www.augment.com/) to name a few, allow users to overlay digital information onto the physical world in the form of images, texts, audio and/or video files, or 3D models and to later view the AR content through a smartphone camera.

AR and VR apps are gaining popularity among ELT practitioners and researchers (e.g., Godwin-Jones, 2016; Hawkinson, Mehran, \& Alizadeh, 2017; Holden \& Sykes, 2011; Reinders \& Lakarnchua, 2014), as their use is aligned with several learning theories, as explained in the following section. 
Theoretical Bases for Using AR \& VR in Education

There are several pedagogical theories supporting the use of interactive media such as AR and VR, including constructivist learning, situated learning, inquiry-based learning, and game-based learning (Bower, Howe, McCredie, Robinson \& Grover, 2014; Chen, 2009;

Dunleavy, Dede, \& Mitchell, 2009). The first theory aligning with AR/VR integration into education is constructivist learning. Unlike older learning theories such as behaviorism, constructivism views learning as an active, contextualized process of knowledge construction (Shrum \& Glisan, 2010). AR and VR technologies support this approach to learning in that they allow learners to construct knowledge from meaningful and enriched experiences otherwise not possible in traditional classroom settings. To gain a clear image of how AR and VR allow for constructivist learning, it is worth revisiting Jonassen's (1994) summary of the implications of constructivism for instructional design in light of AR/VR integration in education. Jonassen stated that knowledge construction may be facilitated in learning environments that

- provide multiple representations of reality; thereby

- avoiding oversimplification of instruction by representing the natural complexity of the real world;

- represent the natural complexity of the real world;

- focus on knowledge construction, not reproduction;

- present authentic tasks (contextualizing rather than abstracting instruction);

- provide real-world, case-based learning environments, rather than predetermined instructional sequences;

- foster reflective practice;

- enable context- and content-dependent knowledge construction; and

support collaborative construction of knowledge through social negotiation, not competition among learners for recognition. (p. 35)

In response to the need for constructivist learning environments, AR and VR are capable of (a) providing multiple representations of reality through adding digital objects to the real world to facilitate the understanding of complex concepts such as human anatomy and solid geometry, as well as immersing learners in virtual learning environments in ways that $2 \mathrm{D}$ multimedia content cannot; (b) representing the natural complexity of the real world by exposing learners to immersive content that focuses on the big picture of phenomena while paying attention to details and that is able to depict the complex interactions among the components of a system that are often underrepresented in mainstream Web 2.0 learning content; (c) focusing on knowledge construction by allowing learners to interact with one another so as to discover facts on their own instead of solely being presented with facts related to a certain topic such as volcanic eruption or photosynthesis; (d) presenting authentic tasks by virtually transporting learners to different contexts, such as allowing them to practice presentation skills in the presence of a simulated audience; (e) providing realworld, case-based learning environments by allowing for personalized learning and the accommodation of various learning styles as well as allowing learners to discover and construct knowledge at their own pace following their own preferred order, thus leading to the creation of individual learning paths; (f) fostering reflective practice by appealing to several different senses-visual, aural, tactile, and others depending on how well configured an AR or VR learning environment is-thus facilitating reflection on and in action (Schön, 1983); and (g) enabling context- and content-dependent knowledge construction by providing context-rich content and gamified problem-solving tasks while making appropriate use of learners' prior knowledge, far from what older methods of knowledge transmission tend to involve.

However, there is a caveat to the statements above, which is that the keys to success in using AR and VR in education are (a) the careful design of tasks so as to ensure that technology integration supports learning and is not merely an end in itself; (b) the ease of task administration and implementation given that educational institutions usually do not have a large budget and most classrooms lack enough space for complicated hardware setup; and (c) user-friendliness of the technology or device for both teachers and students.

Apart from supporting constructivist learning, the use of AR/VR also enables learners to engage with peers in social interactions within a natural learning environment, thus supporting situated learning. Lave and Wenger (1991) argued that a fundamental aspect of learning is its situated nature. This suggests that where, when, with whom, and by what means students learn profoundly affects their learning. AR and VR technologies are capable of enhancing the learning context not only in case of historical topics (such as learning about a historical period by taking students on a virtual tour) but also in any subject matter that can benefit from bringing the real-life learning scene to the classroom by providing context-rich 3D AR simulations.

Moreover, by appealing to learners' sense of curiosity, AR- and VR-supported education can get learners involved in inquiry-based learning, and instead of directly being presented with facts by the teacher, students can experience learning through discovery with the assistance of a facilitator. Last but not least, the game-like features 
of AR and VR learning tasks can more easily get the learners engaged and can often "edutain" (Buckingham \& Scanlon, 2000) them in contrast to what traditional classroom tasks and activities often do.

\section{Virtual and Augmented Reality Apps}

This section introduces some VR and AR apps, provides usage instructions, and clarifies their educational affordances.

\section{Google Expeditions VR}

Google Expeditions VR (https://edu.google.com/products/vr-ar/expeditions/) is a VR educational platform. With Expeditions, teachers can take students on virtual trips to festivals, museums, mountains, oceans, and outer space to name a few examples, without leaving the classroom. At the time of its release in 2015, there were about 500 expeditions available, and approximately twice as many have been developed since then. Expeditions consist of $360^{\circ}$ photos annotated with descriptions and marked with specific points of interest called "spaces." What makes the expeditions engaging is that they are not just tours to majestic places like Mount Everest, the International Space Station, or the Great Barrier Reef. The app can take teachers and students to places that they may not be able to physically visit due to lack of time, geographic distances, and safety issues. For instance, going on a field trip to a volcanic complex like Tolbachik in Russia is not easy, if not impossible. Perhaps the best one could do is to use news articles and videos to describe the place to students, but now with Expeditions, teachers can take them to the heart of the volcanic complex to give them a first-hand experience beyond merely reading texts, seeing images, or watching videos. These expeditions are not only valuable in and of themselves, but they also could be adapted to language learning contexts. Given that all the expeditions come with written annotations on the guide's (in other words, teacher's) menu and include audio narration in VR mode, they could be adapted to various language learning pre- and post-Expedition tasks involving the four skills, vocabulary, grammar, discussion, and so forth. For instance, a virtual visit to Chernobyl could be followed by a discussion on the advantages and disadvantages of establishing nuclear power plants. As another example, students could learn new words and reinforce their knowledge of vocabulary related to museums and artifacts after virtually visiting a museum.

In order to set up Google Expeditions, all that is needed is a tablet for the teacher, smartphones for the students (a BYOD, or bring-your-own-device approach, should work in most contexts), VR goggles such as Google Cardboard, and a router that allows the app to run over the school's wireless local network. However, even if a school or university does not have a stable Wi-Fi connection to download the VR content simultaneously on all student devices, that does not pose a problem. The developers have already taken care of this issue by making the virtual tours downloadable and accessible offline on the teacher's device. That device then operates as a local server for each of the connected student devices, as shown in Figure 3.

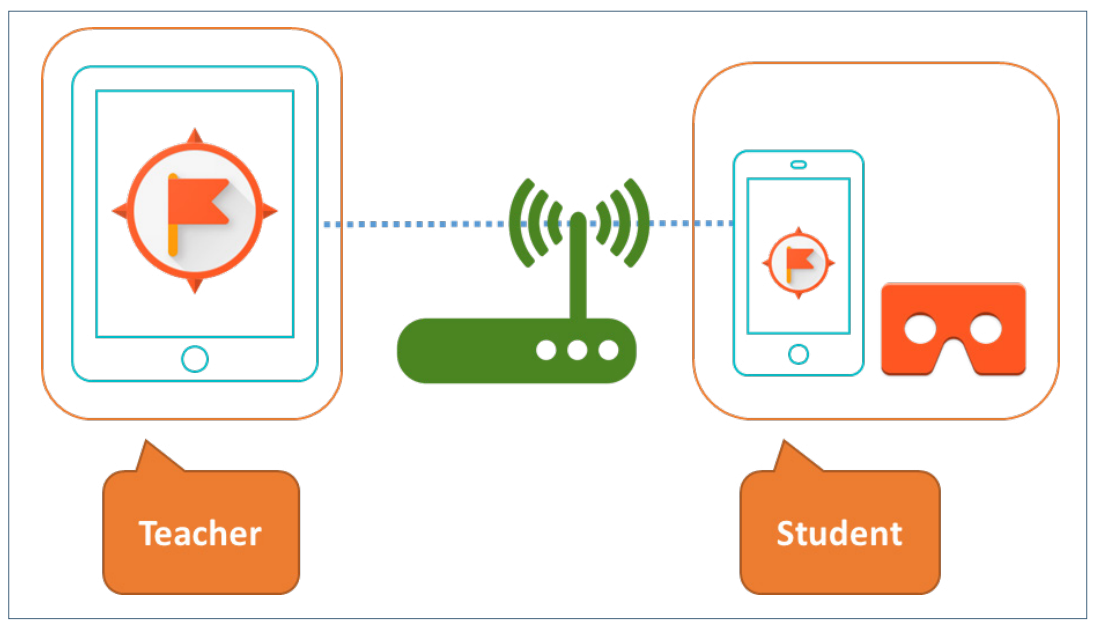

Figure 3. Google Expeditions kit.

Just like in an ordinary class, the teacher needs to able to direct the students in the VR environment, get their attention, and monitor what they are working on. To fulfill this purpose, the app has a guide menu and a pause button on the teacher's device. When the pause button is pushed, the students' screens go black, and the teacher has the chance to get their attention when necessary. Moreover, in order to check what the students are focused on, smiley faces on the teacher's screen act as a sight indicator, indicating what students are looking at (Figure 4). The teacher's menu also includes a description of the location along with several points of interest previously referred to as scenes. When a teacher points out a space on their tablet, an arrow appears on the students' devices directing them to look in that particular direction. Because of these features, the Expeditions experience is far from an isolated activity. It is worth mentioning that 
even without VR goggles, the students can still participate in a virtual tour by looking at smartphone screens in the so-called "magic window" mode (Figure 5); however, with a Cardboard or similar VR viewer, the experience is much more immersive.

Google Expeditions can be integrated into lessons in many ways. The expeditions were initially tagged with target groups and subject matter; however, the tags were eventually removed in order to allow teachers to utilize the tours as creatively as possible. As a result, it is possible to use the same expedition with elementary school children, university students, and adults in lifelong learning programs. For instance, career-related expeditions can be integrated into an EFL/ESL lesson with the theme of jobs and future career. With Expeditions, students can go on virtual internships while having immersive experiences of various occupations and their advantages and drawbacks. As a follow-up task, they can later be asked to share what they find out about different jobs with their classmates.

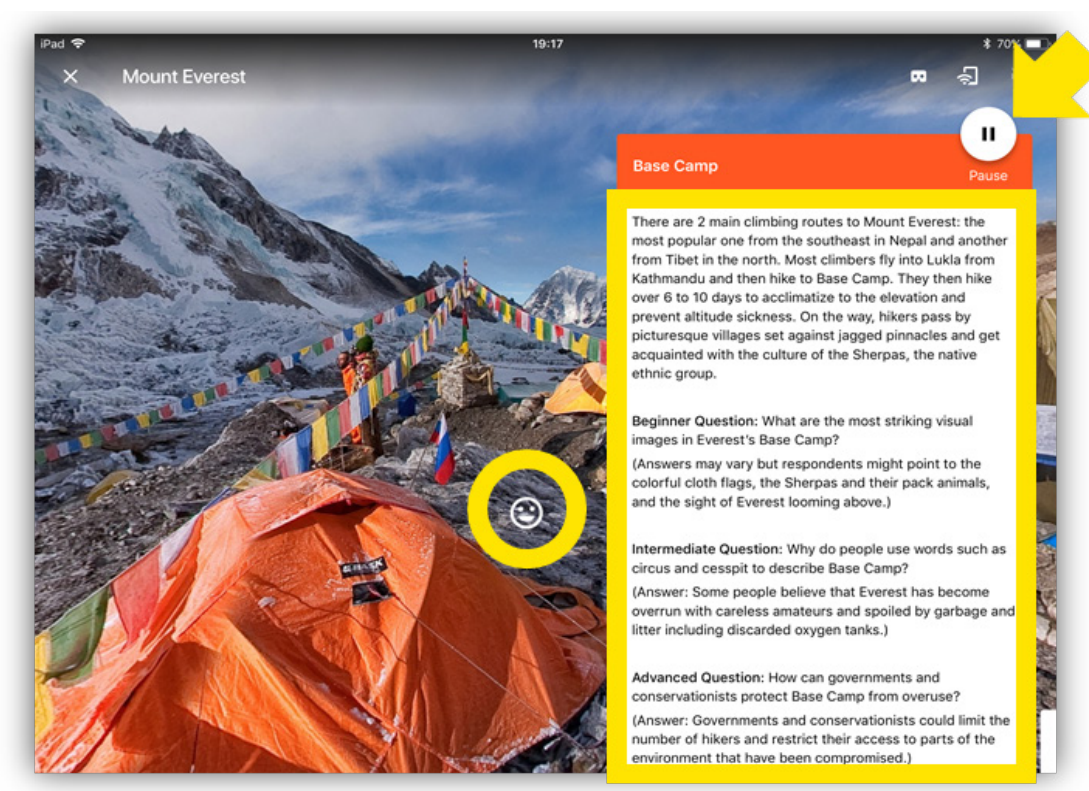

Figure 4. Screenshot of the teacher's menu in Google Expeditions.

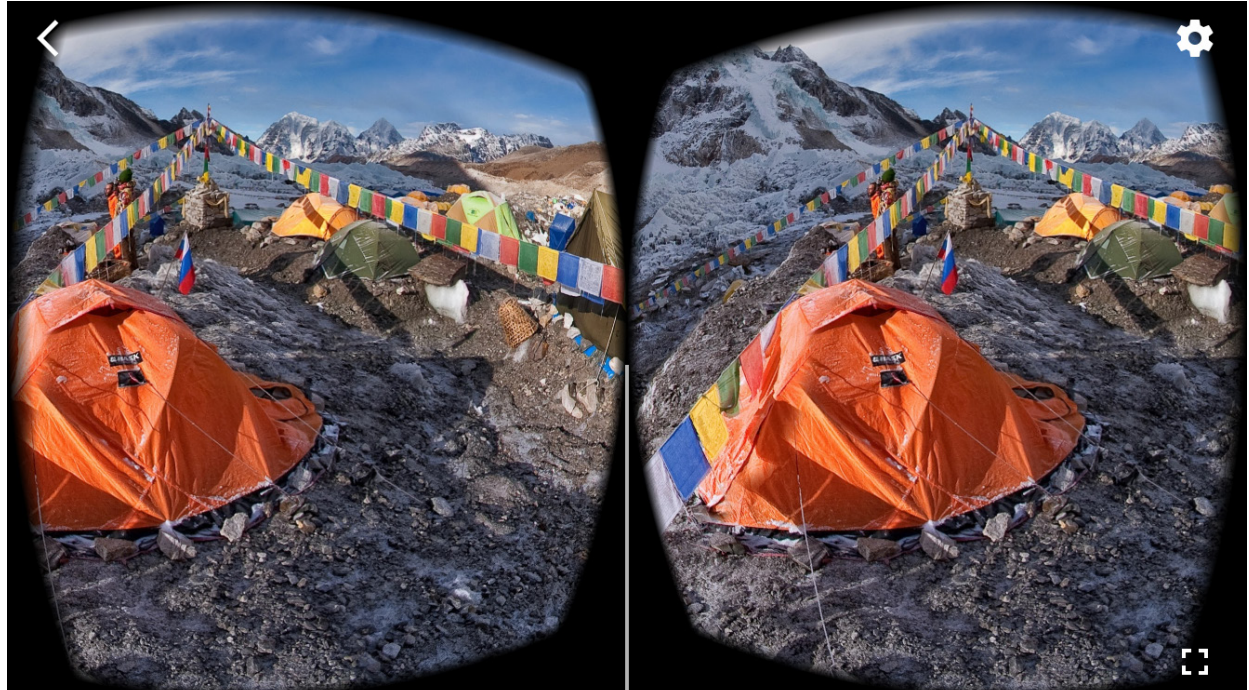

Figure 5. Magic window mode in Google Expeditions.

\section{Tour Creator}

In May 2018, Google released the platform Tour Creator, which allows anyone to create customized VR tours using Google Street View or their own $360^{\circ}$ photos. With Tour Creator (https://vr.google.com/tourcreator/), users can generate quality VR content and create their own spherical VR tours without any knowledge of coding, add points of interest to their tours, and overlay $2 \mathrm{D}$ images to those points of interest so that viewers can further explore them in more detail. The tours created can later be published via Poly (https://poly.google.com/), Google's 3D content library, as well as the Expeditions app and viewed on a mobile device or by using Desktop or Cardboard. For example, studentgenerated VR tours can be used for digital storytelling tasks in L2 classes. More classroom ideas include utilizing relevant Expeditions in EMI (English-medium instruction) classes focusing on subjects such as geography, history, literature, and science.

\section{Google Expeditions AR}

The Google Expeditions development team have taken one step further by adding AR expeditions to the existing app. As of now, AR tours in Expeditions are only compatible with ARCore Android and ARKit iOS phones. However, even if a phone does not 
support AR, the tours can be viewed in 3D on the phone/tablet screen. Similar to Google Expeditions VR, AR expeditions require students to join the same network as the teacher, and in order to go on AR tours, they need to scan the markers preprinted by the teacher and put up around the classroom. The markers can be downloaded through the app or a publicly shared Google Drive folder (accessible at https://rive.google.com/ file/d/1xOXChdSM5tSxZLkBLnci3QZRTLO1-uDe/view). Google Expeditions AR is particularly appealing to teachers of CLIL (content and language integrated learning) and EMI courses because the AR tours can highly facilitate the comprehension of complex concepts in a second language, such as the human skeletal system depicted in Figure 6 . Apart from Google Expeditions, there are several other mobile AR apps, two of which are introduced in the Appendix.

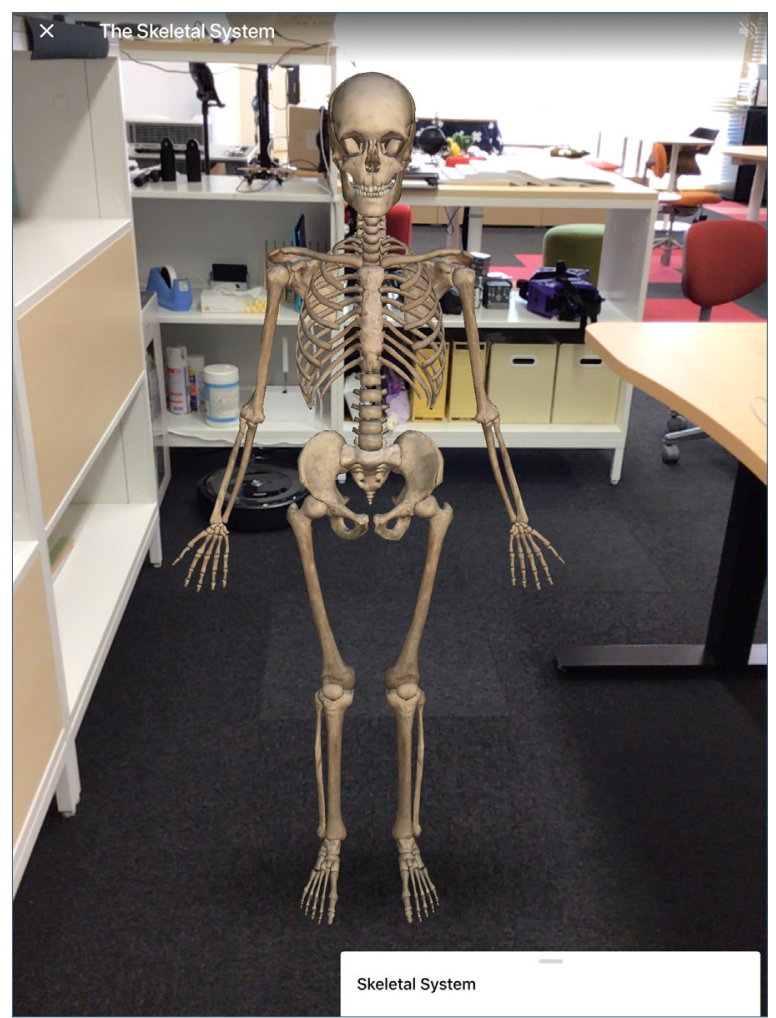

Figure 6. The skeletal system AR Expedition, scene 1.

\section{AR/VR Community of Practice: MAVR SIG}

For readers who wish to explore the possibilities of VR and AR in language education in more depth, the new Mixed, Augmented, and Virtual Realities special interest group may be of interest. This SIG was established in 2017 as part of the Japan Association for Language Teaching (JALT), with the majority of members based in Japan. The SIG officers have been attempting to organize face-to-face and virtual events to connect researchers and practitioners involved in MAVR applications. For instance, a joint Tweet chat was organized with the International Association of Teachers of English as a Foreign Language (IATEFL) Learning Technologies Special Interest Group (LT SIG) in May 2018 with participants from around the world including Japan, the U.K., Germany, and Brazil. The MAVR officers and members have also actively held forums at annual JALT conferences such as PanSIG and the JALT International Conference and have so far organized a joint workshop with the Kyoto Chapter on the use of VR in language education. Further information about the SIG can be found on the group's website (http://mavr.site).

\section{Conclusion}

In this paper I have presented the basic concepts of augmented and virtual reality in relation to learning theories such as constructivist learning and situated learning and have attempted to clarify the connection between these theories and the use of AR and VR technologies in language learning. To that end, some AR and VR apps have been introduced and their use in language learning contexts has been discussed. AR and VR technologies are still new to language educators; nonetheless, there are many possibilities for incorporating them into language learning and teaching, such as enhanced motivation and engagement as well as contextualized learning. Some of these technologies are still in research and development stages, yet it will not be too long before they are normalized, similar to other tools and resources that teachers use on a daily basis. There is no doubt that more research needs to be conducted before we can draw further conclusions regarding the effectiveness of AR and VR integration in language learning; however, a major part of a successful integration hinges upon creative yet meaningful task design.

\section{Bio Data}

Mehrasa Alizadeh is a specially appointed assistant professor at the Language Education Support Research Division, Cybermedia Center, Osaka University. Her areas of interest include computer assisted language learning and AR/VR applications in language education.<mehrasa@cmc.osaka-u.ac.jp> 


\section{References}

Bonner, E., \& Reinders, H. (2018). Augmented and virtual reality in the language classroom: Practical ideas. Teaching English with Technology, 18(3), 33-53. Retrieved from https://files.eric. ed.gov/fulltext/EJ1186392.pdf

Bower, M., Howe, C., McCredie, N., Robinson, A., \& Grover, D. (2014). Augmented reality in education: Cases, places and potentials. Educational Media International, 51(1), 1-15. https://doi org/10.1080/09523987.2014.889400

Buckingham, D., \& Scanlon, M. (2000, November). That is edutainment: Media, pedagogy and the marketplace. Paper presented at the International Forum of Researchers on Young People and the Media, Sydney, Australia.

Chen, C. J. (2009). Theoretical bases for using virtual reality in education. Themes in Science and Technology Education, 2(1-2), 71-90.

Craig, A. B. (2013). Understanding augmented reality: Concepts and applications. Amsterdam, the Netherlands: Morgan Kaufman.

Dunleavy, M., Dede, C., \& Mitchell, R. (2009). Affordances and limitations of immersive participatory augmented reality simulations for teaching and learning. Journal of Science Education and Technology, 18(1), 7-22. https://doi.org/10.1007/s10956-008-9119-1

Gadelha, R. (2018). Revolutionizing education: The promise of virtual reality. Childhood Education 94(1), 40-43. https://doi.org/10.1080/00094056.2018.1420362

Godwin-Jones, R. (2016). Augmented reality and language learning: From annotated vocabulary to place-based mobile games. Language Learning \& Technology, 20(3), 9-19. Retrieved from https:// www.lltjournal.org/item/2961

Hastings, C., \& Brunotte, J. (2017). Total immersion: VR headsets in language learning. In G. Brooks, The 2016 PanSIG Journal (pp. 101-106). Tokyo, Japan: JALT. Retrieved from https://www. pansig.org/publications/2016/2016_PanSIG_Journal.pdf

Hawkinson, E. (2014). Augmented reality enhanced materials design for language learning. In Asian conference on technology in the classroom 2014 official proceedings (pp. 155-161). Osaka, Japan.

Retrieved from https://www.academia.edu/7666533/Augmented_Reality_Enhanced_Materials_ Design_for_Language_Learning

Hawkinson, E., Mehran, P., \& Alizadeh, M. (2017). Using MAVR to bring new dimensions to the classroom. The Language Teacher, 41(3), 30-32. Retrieved from http://jalt-publications.org/sites/ default/files/pdf-article/41.3tlt-wired.pdf

Holden, C. L., \& Sykes, J. M. (2011). Leveraging mobile games for place-based language learning. International Journal of Game-Based Learning, 1(2), 1-18. https://doi.org/10.4018/ ijgbl.2011040101
Jonassen, D. H. (1994). Thinking technology: Toward a constructivist design model. Educational Technology, 34(4), pp. 34-37. Retrieved from https://www.jstor.org/stable/44428173

Kipper, G., \& Rampolla, J. (2013). Augmented reality: An emerging technologies guide to AR. Waltham, MA: Syngress.

Lave, J., \& Wenger, E. (1991). Situated learning: Legitimate peripheral participation. Cambridge, England: Cambridge University Press.

Lege, R., \& Bonner, E. (2018). The state of virtual reality in education. The Language and Media Learning Research Center Annual Report, 149-156. Retrieved from http://id.nii. ac.jp/1092/00001460/

Li, S., Chen, Y., Whittinghill, D. M., \& Vorvoreanu, M. (2015). A pilot study exploring augmented reality to increase motivation of Chinese college students learning English. The ASEE Computer in Education Journal, 6(1), 23-33. Retrieved from http://asee-coed.org/index.php/coed/article/ download/Li_A_Pilot/216

Lloyd, A., Rogerson, S., \& Stead, G. (2017). Imagining the potential for using virtual reality technologies in language learning. In M. Carrier, R. M. Damerow, \& K. M. Bailey (Eds.), Digital language learning and teaching: Research, theory, and practice (pp. 222-234). New York, NY: Routledge.

Milgram, P., Takemura, H., Utsumi, A., \& Kishino, F. (1994). Augmented reality: A class of displays on the reality-virtuality continuum. In H. Das (Ed.), Proceedings of SPIE: Vol. 2351. Telemanipulator and telepresence technologies (pp. 282-292). Bellingham, WA: SPIE.

Reinders, H., \& Lakarnchua, O. (2014). Implementing mobile language learning with an augmented reality activity. Modern English Teacher, 23(2), 42-50.

Santos, M. E. C., Lübke, A., Taketomi, T., Yamamoto, G., Rodrigo, M. M. T., Sandor, C., \& Kato, H. (2016). Augmented reality as multimedia: The case for situated vocabulary learning. Research and Practice in Technology Enhanced Learning, 11(4), 1-23. https://doi.org/10.1186/s41039-016-0028-2

Schön, D. A. (1983). The reflective practitioner: How professionals think in action. New York, NY: Basic Books.

Sherman, W. R., \& Craig, A. B. (2003). Understanding virtual reality: Interface, application, and design Amsterdam, the Netherlands: Morgan Kaufman.

Shrum, J. L., \& Glisan, E. W. (2010). Teacher's handbook: Contextualized language instruction (4th ed.). Boston, MA: Heinle.

van Arnhem, J.-P., Rose, M., \& Elliott, C. (2018). AR U ready for AR/VR? An overview of augmented and virtual reality in libraries. In J.-P. van Arnhem, C. Elliott, \& M. Rose (Eds.), Augmented and virtual reality in libraries (pp. 3-30). Lanham, MD: Rowman \& Littlefield. 


\section{Appendix}

Augmented Reality App 1: BlippAR

BlippAR is an AR platform that allows users to create AR content on a freemium account and to experience the content, also known as a Blipp, using a test code. After creating an account, one can start making Blipps from the dashboard.

BlippAR is a marker-based AR system, meaning that in order to view the AR content, a real-world image or object needs to be scanned using the BlippAR app. Marker requirements can be found on BlippAR help page, "Choosing a Marker" (check https:// support.blippar.com/hc/en-us/articles/208577187-Choosing-a-Marker for further details), but it is important to bear in mind that the more points of contrast a marker has, the more appropriate it is. In other words, busier, more complex, and unique photos make good markers. A first-time user with little experience in selecting markers will be able to generate one through BlippAR. After selecting the marker, the next step is to overlay an asset on it, be it an image, audio, video, or 3D model. Figure 7 displays an image of Granship, the JALT2018 conference venue, selected as the marker with the conference logo (a PNG image file) overlayed on it. This page allows users to make changes to the style and layout of an asset by making changes to its position, opacity, and so forth.

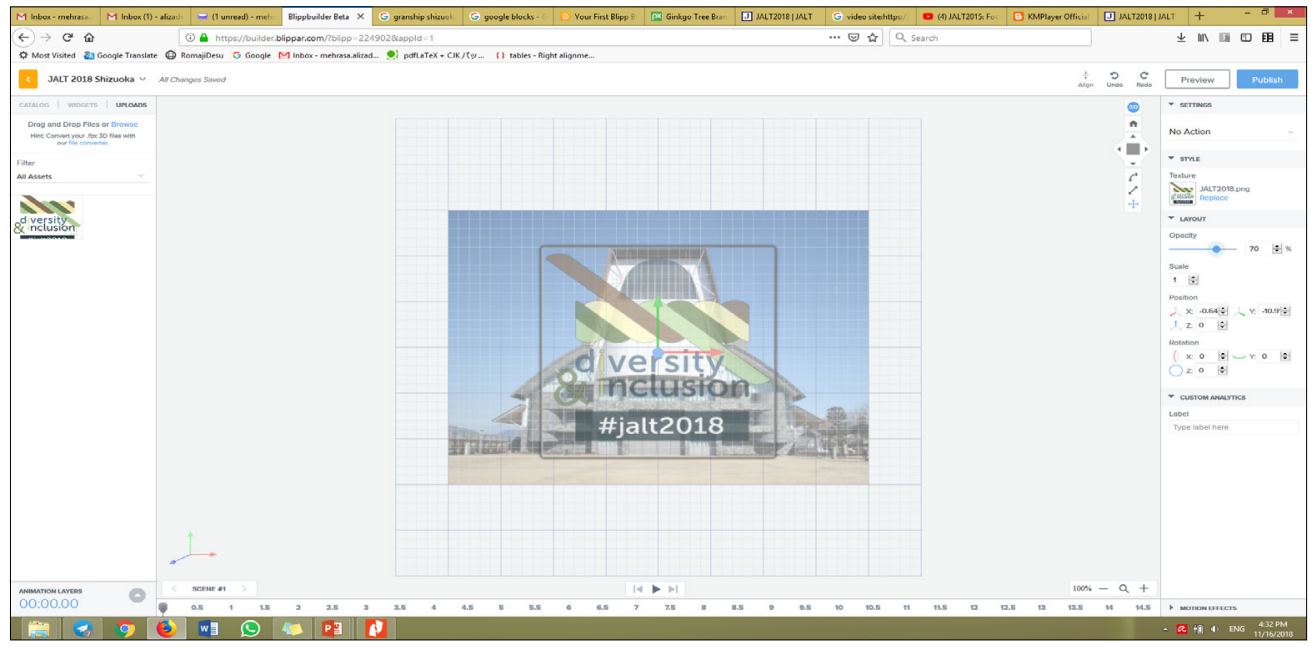

Figure 7. An image overlay on a marker.
On a freemium account, a user can publish their Blipps to test but not to live unless they upgrade to a premium account (Figure 8). A test code needs to be between 3 and 15 characters.

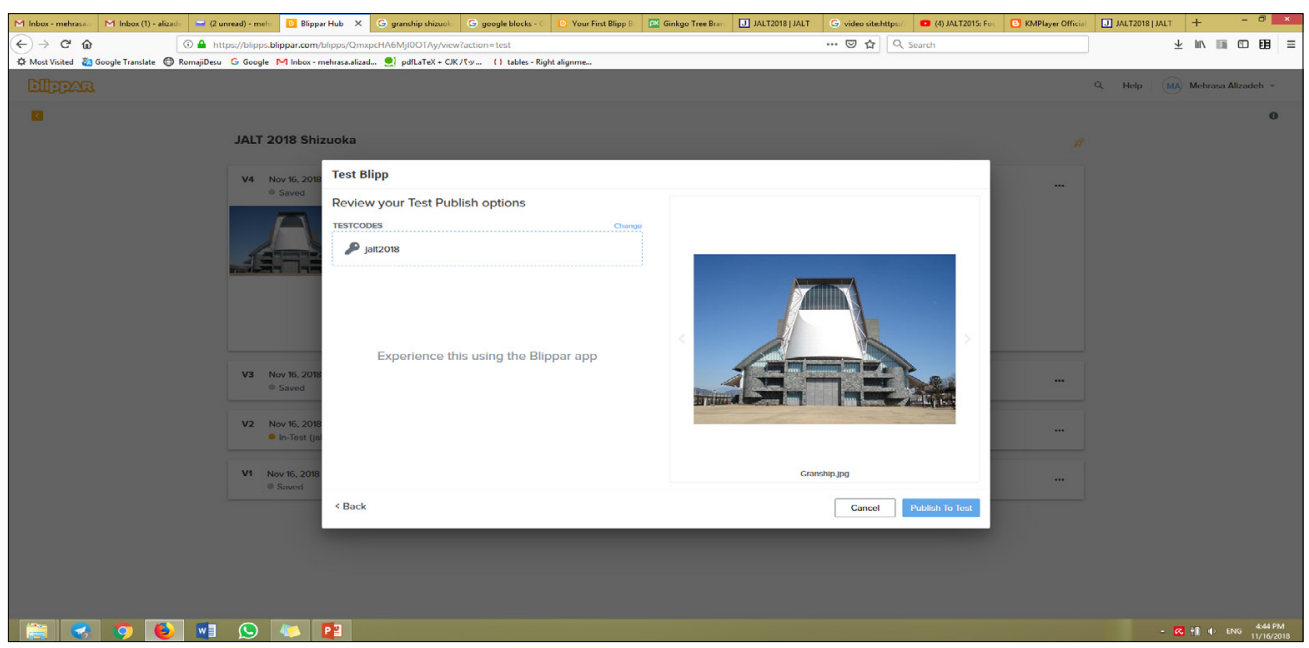

Figure 8. Set a test code and publish to test.

After publishing a Blipp to test, a user can view the AR content by entering the designated code into the app and scanning the marker. For example, if a user has downloaded the BlippAR app, enter the code "jalt2018" and scan the image in Figure 9. To view the overlaid asset, keep the button on the screen pressed for a while and then let go of it. One should be able to see the conference logo on top of the image of Granship. 


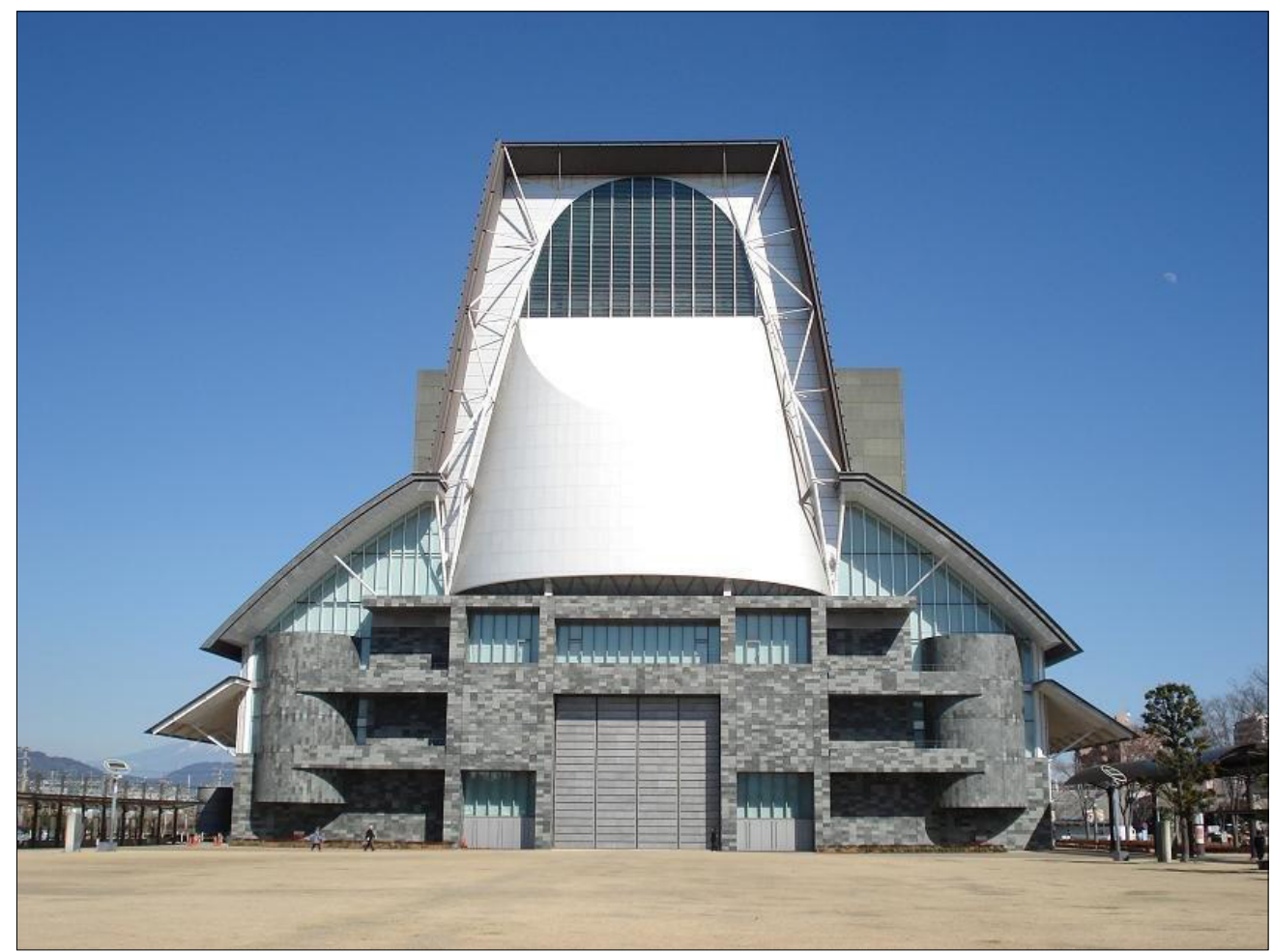

Figure 9. Image of Granship, JALT2018 conference venue.

\section{Augmented Reality App 2: HP Reveal}

HP Reveal (formerly known as Aurasma) is another AR mobile application that allows creating, viewing, and sharing AR content. Overlays can be selected from the HP Reveal library or alternatively uploaded from users' devices. Unlike BlippAR, entering a code is not necessary; however, to view Auras (AR content created with HP Reveal) from other users, one needs to follow their account first. Bonner and Reinders (2018) have provided several practical ideas for using HP Reveal and similar AR apps in the classroom for a variety of language-related tasks such as creating campus tours, giving and following directions, going on location-based puzzle treasure hunts, providing instant-access supplementary materials for readings, automatically assigning roles in information gap activities, and backchanneling with the teacher during classwork or homework. 